International Journal of Management and Human Science

www.ijmhs.org

\title{
Documentation of the Minor Edible Fruits Sold in Phoolbagan, Kolkata, India
}

\author{
Mitu De \\ Department of Botany, Gurudas College, Kolkata, India \\ Corresponding Author's E-Mail: mitude@ rediffmail.com
}

\begin{abstract}
Most of the underutilized minor fruits of the tropics are often available only in the local markets. They are usually relatively less palatable than other commercial fruits. Minor fruits generally have lesser demand in the market. They are usually very resilient and can adapt to the local climate. Literature review reveals that minor edible fruits play a vital role as food and medicine. Along with humans, many birds and animals eat these minor fruits. These minor fruits are part of our indigenous fruit legacy. Sometimes these minor fruits are sold in temporary shops by individuals who bring them from the districts into the city. Documentation of the minor edible fruits in different areas will help in making a comprehensive database of these underutilised fruits in local areas. There need to be extensive awareness drives so that the urban population becomes aware of the nutritional status of these minor fruits. Awareness drives need documentation of existing minor fruit diversity first. This paper is a documentation of the minor edible fruits sold in Phoolbagan near Gurudas College.
\end{abstract}

Keywords: Minor Edible Fruits, Underutilised Fruit, Documentation, Indigenous Fruit Legacy

\section{Introduction}

Some fruits don't have great demand in the fruit market. Though these fruits are consumable to human beings but are relatively less palatable than other mainstream fruits. So, they are either grown to a limited extent or are not cultivated at all (Srivastava, Bishnoi \& Sarkar, 2017). The important fruit crops grown commercially in India are mango, banana, Citrus sp, guava, grape, pineapple, papaya, sapota, litchi and apple which comprise more than 75 percent of the total area under fruit cultivation (Mitra, Pathak \& Chakraborty, 2010). All the underutilized fruit trees and shrubs together comprise the rest 25 percent. Sometimes they are 
grown along the roadsides or on uncultivated tracts of land. Sometimes these minor fruits are sold in temporary shops by individuals who bring them from the districts into the city.

Most of the underutilized fruits of the tropics are often available only in the local markets and are practically unknown to other parts of the world (Porika et. al., 2019). They are usually not are not cultivated in large tracts of land (Roy \& Bauri, 2019). Since the area under each of these fruit trees is insignificant, they are popularly known as 'minor fruits' or 'underutilized fruits'. Dr. B.C. Mazumdar, Professor in Horticulture, Institute of Agricultural Science, Calcutta University in his book 'Minor Fruit Crops of India: Tropical and Subtropical' gave the definition of minor fruits as "those fruits which though are consumable to the human beings but relatively less palatable than other fruits, which have lesser demand in the market, which are grown to a limited extent only and are not usually cropped in organized plantations with application of inputs are considered in grouping as minor fruit crops" (Mazumdar, 2004).

\section{Documentation of Edible Minor Fruit}

In many floristic works on the Indian sub-continent, there has been documentation of the minor fruits and wild edible fruits viz. Assam (Humphrey, Carter \& Dorine, 1921); Bangladesh (Rahman \& Rahman, 2014); Indian Himalayas (Joshi, 1998); Sikkim (Suresh et al., 2014) and Tripura (Majumder \& Dutta, 2009; Das et al., 2013). The Food Plants International database documents 4,973 edible plants in India, 1,170 in Sri Lanka and 11,155 for the broader Asia region (French, 2019).

\section{Utility of Edible Minor Fruits}

Researchers who have worked with underutilised fruits are of the opinion that minor edible fruits play a vital role in food and medicine. They are the genetic resource of any country and have an impact on the nutrition of the population (Pasha \& Uddin, 2019). There have been several research works on the utility and importance of minor fruits (Mitra, Pathak \& Chakraborty, 2008; Majumder \& Dutta, 2009; Malik et al., 2010; Mahapatra \& Pratap, 2012). Different aspects of the nutritional value of these underutilized fruits have been studied and documented by researchers (Mitra, Pathak \& Chakraborty, 2008; Seal, 2011). Some of these minor fruits are eaten raw. Some are cooked or made into pickles before consumption.

\section{Study Site}

Phoolbagan is an area in Kolkata that is connected to both Sealdah and Ultadanga railway stations that connect the North \& South 24 Parganas districts. Phoolbagan is well connected by road too with different parts of the city and districts. Local residents of the districts often bring minor fruits to the city. They set up temporary shops by simply placing some newspaper or plastic sheets on the ground and selling them. At the end of the day, the plastic sheets are folded, and the persons return home.

Gurudas College is an undergraduate college located in Phoolbagan in Kolkata, West Bengal, India. The coordinates of the college are $22.5712^{\circ} \mathrm{N}, 88.3905^{\circ} \mathrm{E}$. It is located in an urban locality in the heart of the city. There is ample green cover on the campus. 


\section{Results}

Minor fruits are seasonal fruits. So, documentation of the fruits that were sold in makeshift shops in Phoolbagan very near Gurudas College took about one year viz. 2019. Students are one big segment of the population who like tangy fruit preparations either raw or as pickles there seemed to be a steady consumer strength for the vendors of these minor fruits. Often the same individual would be selling different minor fruits during different seasons. Table I gives a list of minor fruits (in alphabetical order) that were sold in Phoolbagan along with their family names and common names. In Table II list of edible minor fruits that were found in the vicinity but generally not sold as raw fruits are given.

Table 1: List of Minor Edible Fruits Sold in Phoolbagan

\begin{tabular}{|c|c|c|c|c|}
\hline $\begin{array}{l}\text { Sl. } \\
\text { No. }\end{array}$ & Scientific Name & Family & $\begin{array}{c}\text { Common Name in } \\
\text { English }\end{array}$ & $\begin{array}{c}\text { Common Name in } \\
\text { Bengali }\end{array}$ \\
\hline 1 & Aegle marmelos (L) Corr. & Rutaceae & Wood apple & Bael \\
\hline 2 & Annona squamosa $\mathrm{L}$. & Annonaceae & Custard apple & Aata \\
\hline 3 & Annona reticulata $\mathrm{L}$. & Annonaceae & Bullock's heart & Nona \\
\hline 4 & $\begin{array}{c}\text { Artocarpus heterophyllus } \\
\text { Lam. }\end{array}$ & Moraceae & Jackfruit & Kathal \\
\hline 5 & Averrohoe carambola $\mathrm{L}$. & Oxalidaceae & $\begin{array}{c}\text { Carambola/ Tree } \\
\text { Sorrel }\end{array}$ & Kamranga \\
\hline 6 & Borassus flabellifer $\mathrm{L}$. & Arecaceae & $\begin{array}{l}\text { Asian Palmyra palm/ } \\
\text { Toddy palm }\end{array}$ & Taal \\
\hline 7 & Citrus grandis Osbeck & Rutaceae & Pumello & Batabi \\
\hline 8 & Dillenia india $\mathrm{L}$. & Dilleniaceae & Dillenia & Chalta \\
\hline 9 & Dimocarpus longan Lour. & Sapindaceae & & Ashphal \\
\hline 10 & $\begin{array}{c}\text { Elacocarpus floribunda } \\
\text { Blume. }\end{array}$ & Elaeocarpaceae & Olive & Jalpai \\
\hline 11 & $\begin{array}{c}\text { Embilica officinalis } \\
\text { Gaertn. }\end{array}$ & Euphorbiaceae & Amla & Amlaki \\
\hline 12 & $\begin{array}{c}\text { Feronia limonea } \mathrm{L} . \\
\text { Swingle }\end{array}$ & Rutaceae & Elephant apple & Kayeth Bael \\
\hline 13 & Ficus hispida $\mathrm{L}$. & Moraceae & Fig & Dumur \\
\hline 14 & Physalis peruviana $\mathrm{L}$. & Solanaceae & Cape Gooseberry & Tapari \\
\hline 15 & Spondius cythera Sonn. & Anacardiaceae & Hog Plum & Amra \\
\hline 16 & Syzygium cuminii L. & Myrtaceae & Indian Blackberry & Jamun \\
\hline 17 & $\begin{array}{c}\text { Syzgium jambos L. } \\
\text { (Alston) }\end{array}$ & Myrtaceae & Rose Apple & Golap Jaam \\
\hline
\end{tabular}




\begin{tabular}{|c|c|c|c|c|}
\hline 18 & $\begin{array}{c}\text { Syzygium samarengense } \\
\text { (Blume) Merrill \& Perry }\end{array}$ & Myrtaceae & $\begin{array}{c}\text { Star Apple/ Wax } \\
\text { apple }\end{array}$ & Jamrul/Jaman \\
\hline 19 & Tamarindus indica L. & Leguminosae & Tamarind & Tetul \\
\hline 20 & $\begin{array}{c}\text { Termenalia bellirica } \\
\text { (Gaertn) Roxb. }\end{array}$ & Combretaceae & Beleric Myrobalan & Bahera \\
\hline 21 & Trapa bispinosa Roxb. & Trapaceae & Water chestnut & Panifal \\
\hline 22 & Ziziphus mauritiana Lamk & Rhamnaceae & Indian Plum/ Jujube & Kul \\
\hline
\end{tabular}

Table 2: List of Minor Edible Fruits Found around Phoolbagan Which Are Obtained Freely from Roadside Trees and Shrubs and Sometimes Sold As Raw Fruits

\begin{tabular}{|c|c|c|c|c|}
\hline $\begin{array}{c}\text { Sl. } \\
\text { No. }\end{array}$ & Scientific Name & Family & $\begin{array}{c}\text { Common Name in } \\
\text { English }\end{array}$ & $\begin{array}{c}\text { Common Name in } \\
\text { Bengali }\end{array}$ \\
\hline 1 & Aegle marmelos (L) Corr. & Rutaceae & Wood apple & Bael \\
\hline 2 & Carissa carandas L. & Apocynaceae & Carandas plum & Karamcha \\
\hline 3 & Dillenia india L. & Dilleniaceae & Dillenia & Chalta \\
\hline 4 & Grewia asiatica L. & Tiliaceae & Blueberry & Phalsha \\
\hline 5 & Masters & & & Bakul \\
\hline 6 & Mimusops elengi L. & Sapotaceae & Spanish Cherry & Tunt \\
\hline 7 & $\begin{array}{c}\text { Pithecellobium dulce } \text { (Ro } \\
\text { xb.) Benth. }\end{array}$ & Fabaceae (s.l.) & Manila tamarind & Jilipi phal \\
\hline 8 & Spondius cythera Sonn & Anacardiaceae & Hog Plum & Amra \\
\hline 9 & Tamarindus indica L & Leguminosae & Tamarind & Tetul \\
\hline 10 & Ziziphus mauritiana & Rhamnaceae & Indian Plum/ Jujube & Kul \\
& Lamk & & & \\
\hline
\end{tabular}

From the above two tables, it is seen that 22 minor edible fruits are sold at different times of the year in Phoolbagan. There are 10 edible minor fruits listed in Table 2 that are usually found growing in roadside trees or shrubs around Phoolbagan, and these are generally not sold.

\section{Discussion}

With unsustainable market pressures and rapid urbanization, the majority of these species have come to near extinction (Diengngan \& Hasan, 2015). However, these underutilized fruit species are usually extremely resilient. They have adapted themselves and can survive harsh agro-climatic conditions. They can be established on degraded lands, which are presently being underutilized either due to poor soil fertility or moisture scarcity 
(Diengngan \& Hasan, 2015). As they are not commercially cultivated their price is generally much lower than the commercial fruits. Minor fruits are adapted to the local climate. Along with humans, many birds and animals eat these minor fruits.

There are many less-known fruit species that have the potential for commercial exploitation but are yet to be utilized to their potential (Pareek \& Sharma, 1993). These minor fruits are usually restricted to localized regions.

They are reported to be highly nutritious and contribute to poverty elevation and the household food security of rural people (Roy \& Bauri, 2019). Minor fruits play a significant role in herbal medicine too (Mallikarjuna et al., 2019). The Food Plants International database which covers 27,000 edible plant species is an excellent way to raise awareness about these minor fruits (French, 2019).

These minor fruits are part of our indigenous fruit legacy. Awareness about these underutilized fruits needs to be a part of the conversation within educational institutions. Short project work could be initiated by teachers associated in schools and colleges to popularise these minor fruits. Ultimately sustained consumption of these fruits can push them away from the brink of consumption.

\section{Conclusion}

These minor fruits are underutilized because there is not much awareness about their nutritional benefits. Apart from diverse nutritional properties, they are also relatively cheaper than commonly cultivated fruits. However, it is often that the low price makes their value seems less within the urban population. There need to be extensive awareness drives so that the urban population becomes aware of the nutritional status of these minor fruits. If there is a demand for these minor fruits among the general population, there is still hope that these species will survive.

\section{Conflict of Interest}

The author declares that she has no conflict of interest.

\section{Acknowledgement}

The author gives thanks to the countless people who come to Phoolbagan many times a year to sell minor fruits. Through them we get a glimpse of the rich minor fruit diversity.

\section{References}

Das, S.C., Prakash, J., \& Deb, A.K., \& Biswas, T. (2013). Medicinal Value of Underutilized Fruits in Hilly Tripura. International Society for Horticultural Science, 972, 135-141.

Diengngan, S., Hasan, M.A. (2015). Genetic Diversity of Underutilized Fruits in India for Environmental Sustainability. Advances in Plants \& Agriculture Research, 2(7), 299-303.

French, B. (2019). Food Plants International Database of Edible Plants of the World: A Free Resource for All. Acta Hortic, 1241, 1-6. 
Gowda, A.P.M., Ranjini, T.N., Peethambar, S.K. \& Praneeth, Y.S. (2019). Underutilized, yet potential medicinal plants of Western Ghats. Acta Hortic. 1241, 15-22.

Humphrey, G., Carter, A. \& Dorine, N. (1978). Useful Plants of the District of Lakhimpur (1 ${ }^{\text {st }}$ ed.). M/s Bishen Singh Mahendra Pal Singh.

Joshi, B.D. (1998). Indigenous horticultural fruits of the Indian Himalayas. In T. Partap \& Sthapit, B. (Eds.), Managing agrobiodiversity: farmers' changing perspectives and institutional responses in the HKH (Hindu Kush-Himalayan) region.

Mahapatra, A.K. \& Panda, P.C. (2012). Wild edible fruit diversity and its significance in the livelihood of indigenous tribals: Evidence from eastern India. Food Security, 4(2), 219-234

Majumder, K., and Dutta, B.K. (2009). Traditional wild edible fruits for the forest dwellers of Tripura, India. East Himalayan Society for Spermatophyte Taxonomy, 3(2), 167-178.

Malik, S. K., Choudhury, R., Dharial, O.P., \& Bhandari, D.C. (2010). Genetic Resources of Tropical Underutilized fruits of India. https://doi.org/10.17660/ACTAHORTIC.2011.918.23

Mazumdar, B.C. (2004). Minor Fruit Crops of India: Tropical and Subtropical. Daya Publishing House.

Mitra, S. K., Pathak, P.K., \& Chakraborty, I. (2008). Potential Use of Underutilized Crops for Nutritional and Medicinal Properties. In J. Smith \& N. Haq (Eds.), New Crops and Uses, Their Role in rapidly Changing world.

Mitra, S.K., Pathak, P.K., \& Chakraborty I. (2010). Potential underutilized tropical fruits of India. Acta Hortic, 864, 61-67.

Pareek O.P., \& Sharma, S. (1993). Underutilized Fruits. Indian Horticulture Journal, 38:4758.

Pasha, M.K. \& Uddin, S.B. (2019). Minor edible fruits of Bangladesh. Bangladesh Journal of Plant Taxonomy, 26(2), 299-313.

Porika, H., Chavan, M., Karosiya, A., \& Suchithra, M. (2019). Under-exploited fruits - a high potential for processing and value addition. Acta Hortic. 1241, 615-626

Rahman, M., \& Rahman, J. (2014). Medicinal value and nutrient status of indigenous fruits of Bangladesh. Nova Journal of Medical and Biological Sciences, 26, 1-19.

Roy, A., \& Bauri, F.K. (2019). Scope of minor fruit production in India. Acta Hortic, 1241, 43-50.

Seal, T. (2011). Antioxidant Activity of Some Wild Edible Fruits of Meghalaya State in India. Advances in Biological Research, 5(3), 155-160

Srivastava, A., Bishnoi, S. K., \& Sarkar, P. K. (2017). Value Addition in Minor Fruits of Eastern India: An Opportunity to Generate Rural Employment. In A. K. Dutta and B. Mondal (Eds.), Fruits for Livelihood: Production Technology and Management Practices. Agrobios.

Suresh, C.P., Bhatia, K.D., Sukla, G., Pradhan, K., \& Chakravarty, S. (2014). Wild Edible Tree Fruits of Sikkim Himalayas. Journal of Tree Science, 33(1), 12-33. 